\title{
Main political and legal problems of religious building construction in the Polish People's Republic between 1945 and 1989
}

Zasadnicze problemy polityczne i prawne budownictwa sakralnego w okresie Polskiej Rzeczpospolitej Ludowej w latach 1945-1989

\section{Introduction}

There are still many controversies surrounding the history of the Polish People's Republic. Time and again, the public learns about prominent figures of political, social or religious life who collaborated with the Communist authorities, as their secret agents. The issues of vetting, assessment of those times, or of how important the Communist state structures have been for building the Third Republic of Poland, often come up in discussions. Unfortunately, many of these discussions are dominated by emotions and commonplace opinions, which does not encourage a fair reflection on this period. The theme of Church-State relations between 1945 and 1989 occupies an important place in these discussions.

There are many publications that deal with the history of the Polish People's Republic and the relations between the Catholic Church and Communist state. Typically, however, researchers focus only on the attitude of the Communist authorities towards the Catholic Church, treating other denominations only peripherally or ignoring them completely. Hence, many issues are still unexplained. One of them concerns the construction of religious buildings by religious associations. This issue was one of the main aspects of the religious policy during the Polish People's Republic.

Religious associations cannot carry out their aims and functions without places of worship and other necessary buildings; hence, by restricting the development of these facilities, the Communist authorities wanted to suppress religious associations that were believed to be hostile to the Polish People's 
Republic. Available source materials, both of the administration for religious affairs and those of the security organs involved in the surveillance of religious communities, show clearly that religious building construction was one of the fundamental issues in the religious policy of the Polish People's Republic. The Communist authorities believed that the erection of churches and other buildings by the Roman Catholic Church was a manifestation of the clergy's power and an attempt to get Polish citizens involved in developing an organisation that was in principle hostile to the People's Republic. At the same time, the policy makers realized that a complete ban on religious building construction would lead to strong opposition to the authorities - especially in those regions of the Polish People's Republic where people were highly devout. Hence, attempts were made to find such ways of suppressing the construction of religious buildings that would not provoke resistance. This required joint and wide-scale efforts of the party and administration authorities, as well as the security organs.

Therefore the main aim of the article is to indicate issues to the mechanisms and legal basis for the activities of the Communist authorities in Poland in regard to sacral building construction. At the same time, in the article, the author analyses the legal and factual possibilities of the faithful as well as religious associations to carry out sacral construction. The article does not analyse the issue of difficulties made by the authorities of the People's Republic of Poland for the faithful to use the already existing temples (e.g. Greek-Catholic). This interesting matter requires further research. The term "religious building construction" is used here to refer to every construction and renovation work carried out by religious associations or their organizational units.

\section{Regulations concerning religious building construction in the Polish People's Republic}

The Constitution of the Polish People's Republic of 22 July $1952^{1}$ set forth the separation of Church and state (Art. 70, sec. 2) and stipulated that the Church could freely carry out its religious functions (Art. 70, sec. 1). This provision referred also to other religious associations (Zieliński, 2010, pp. 183-210). Under the constitutional law at that time, the freedom of religion was understood as the freedom to proclaim doctrine, organize religious assemblies, provide ministry

\footnotetext{
${ }^{1}$ Konstytucja Polskiej Rzeczypospolitej Ludowej uchwalona przez Sejm Ustawodawczy w dniu 22 lipca 1952 r., Dz.U. 1952, nr 33, poz. 232.
} 
and teaching, establish religious orders, and maintain contacts with the believers abroad (Godlewski \& Jabłoński, 1988, pp. 53-54). However, even before the Constitution had been enacted, a number of legal acts were passed, which blatantly limited the freedom of religious associations. The law was used to discriminate against the Catholic Church, which soon became standard behaviour. For example, legal measures, especially penal and administrative sanctions, were employed to block and restrict the construction of buildings used for religious purposes by Roman Catholics (Misztal, 1997, p. 320). However, interestingly enough, the construction of religious buildings by other religious associations, e.g. by the Orthodox Church or the Reformed communities, was looked on favourably, or even supported by the authorities. For example, in the documents of the Department for Religious Affairs in Rzeszów, one can come across the statement that the authorities were interested in developing the facilities of the Orthodox Church and encouraged its activities as a sort of "counterbalance" to the influences of the Roman Catholic Church. The communities that had their origins in the Reformation in the "recovered territories" were treated in a similar way (Misztal, 1997, p. 320). This opens up an issue of treating religious associations in an instrumental way and using the antagonisms between them in order to achieve the political and religious goals that the Communist authorities set themselves. Moreover, it puts into question the opinion, which is commonly adopted in literature, that the Communist authorities in Poland had an entirely negative attitude to religiosity.

From the point of view of historical and legal research into the times of the Polish People's Republic, it is crucial to get access to internal regulations which were used by the state authorities and often determined the decisions issued by them. It is equally important to examine materials documenting various meetings, correspondence between the state and party organs, or plans outlining the aims of religious policy. The fact that administrative decisions or operational actions were taken on the basis of political directives rather than in compliance with properly applied legal norms, has often been described in the literature concerning the Polish People's Republic.

The main legal act concerning religious building construction was Circular No. 3 on the construction of sacred and ecclesiastical buildings and on providing them with building materials, dated 27 March 1957 and issued by Head of the Office for Religious Affairs (Okólnik nr 3 Kierownika Urzędu do Spraw Wyznań z dnia 27 marca 1957 r. w sprawie budownictwa obiektów sakralnych i kościelnych oraz zaopatrywania tych obiektów w materiały budowlane). The document was not released officially. For political reasons, it introduced a distinction between 
buildings used for worship (construction, extension, reconstruction and renovation of churches or chapels) and ecclesiastical buildings (other buildings where a church institution was an investor - e.g. construction or renovation of parish houses). The Building Law Act (Ustawa z dnia 31 stycznia 1961 r. - Prawo budowlane), which contained, among other things, regulations on the construction of religious buildings, was passed in 1961. It introduced a new broader definition of a building structure, including chapels and other worship structures (Art. 1 sec. 4, (1) and made it much more difficult to erect them legally. In addition, pursuant to this Act, Church legal persons could carry out construction related only to their activities recognized by law. These restrictions were eased by the Building Law Act of 1974 (Ustawa z dnia 24 października 1974 r. - Prawo budowlane), which allowed, for example, to erect monuments, statues, chapels, crosses and other similar religious structures as long as they were located in cemeteries and church areas where religious worship was exercised (\$19.2).

The 1957 circular was repealed only in 1981, by the Prime Minister's decree of 24 November 1981 (Zarządzenie nr 47 Prezesa Rady Ministrów z dnia 24 listopada 1981 roku w sprawie planowania i realizacji inwestycji sakralnych i kościelnych). Another change, this time a major one, concerning the legal status of religious building construction took place in the twilight of the Polish People's Republic, when the Act on Relations between the State and the Catholic Church in the Polish People’s Republic (Ustawa z dnia 17 maja 1989 r. o stosunku Państwa do Kościoła katolickiego w Polskiej Rzeczypospolitej Ludowej) and the Act on Guarantees of Freedom of Conscience and Religion were passed (Ustawa z dnia 17 maja 1989 r. o gwarancjach wolności sumienia i wyznania). For the first time in post-war history of Poland, these acts expressly guaranteed the right to carry out the construction of sacred and ecclesiastical buildings. However, in order to prevent religious communities from constructing religious buildings, the State Treasury frequently took over the land intended for such purpose or the land on which a religious building had already been erected. In addition, numerous methods were used to preclude religious associations from purchasing building plots. The area development plans were frequently prepared in such a way as to stop the faithful from erecting a building of any type. It is also noteworthy that while the Communist authorities prevented the Roman Catholic Church from developing its facilities, they encouraged and supported those Catholic and non-Catholic associations that were established by them. In addition, the authorities tried to draw people away from taking part in the construction of religious buildings, by organizing the so called "voluntary community service" or by offering to construct other public buildings (e.g. a school, a people's house, 
or a shop) in a town. Another important way of preventing church building was propaganda in the media.

\section{The policy of the State towards the religious building construction}

Obviously, in the centralist system of the Polish People's Republic, directives issued by the highest state organs, in particular by the party's leadership, determined specific actions of local authorities. In many cases, the local authorities requested some guidelines on how to solve problems that they encountered, or they put forward their own proposals for nationwide policy on religion. For example, they repeatedly called for unifying the policy concerning religious building construction in the whole country, in order to prevent priests from claiming that the authorities in one voivodeship were better-disposed than those in some other. From a legal point of view, especially from the perspective of the research project, this situation generates some extremely interesting research problems - first and foremost, concerning the question of how the same legislation was applied differently ${ }^{2}$.

From the reports submitted by local authorities, it is clear that the goals and methods of implementing religious policy in regard to religious building construction varied greatly from region to region. These differences were visible primarily in how the same legal regulations were applied, depending on political and religious factors. Previous research into this period in the field of historiography and the study of law, has focused primarily on issues connected with the policy of the Communist authorities towards the Roman Catholic Church, whereas the policy towards non-Catholic religious associations has not been studied. Likewise, the issue of religious building construction has been studied only in relation to the Roman Catholic Church. Important as this subject is, there is no publication that deals with the policy of the Communist authorities in regard to the construction of sacred and ecclesiastical buildings by other religious associations

Moreover, there are other vital issues concerning religious policy that are connected with religious building construction. These are: controlling appoint-

${ }^{2}$ See Informacja o realizacji zadań w zakresie polityki wyznaniowej, Archiwum Akt Nowych (next: AAN), zespół 1587, sygn. 127/67, k. 29; Charakterystyka i ocena polityki wyznaniowej na terenie województwa kaliskiego w okresie 1.09.1975-1.09.1977, AAN, zespół 1587, sygn. 127/67, k. 81-85; Zasady, problemy i zadania polityki wyznaniowej w Polsce, AAN, zespół 1587, sygn. 142/4, k. 18. 
ments of priests, creating new units of religious associations, or repressions of the clergy and lay followers. The clergy's attitude towards religious building construction was seen as the main indicator of their general attitude towards the Polish People's Republic, which, in turn, determined legal sanctions imposed on priests. Archival research shows that the methods of implementing religious policy on the construction of religious buildings in the Polish People's Republic varied significantly (e.g. in respect of penal and administrative sanctions imposed for starting a construction process illegally, granting permits and subsidies for conservation work, as well as ways of treating reformed communities, their missionary activity and plans to develop necessary facilities). An analysis of archival materials concerning religious policy during the Polish People's Republic shows that the treatment of religious associations was mainly determined by how the Communist authorities assessed the "political attitude" of leaders of those communities. For example, the Office for Religious Affairs instructed its regional branches to support, both financially and organizationally, those religious associations whose attitude to the Polish People's Republic was "in accordance with the constitutional principles". At the same time, the Office recommended cracking down on those communities that were believed to be hostile to the Communist Poland.

Changes in the repressive policy of the Communist authorities, especially towards the Catholic Church, took place as a result of the growing public opposition to the authorities in the years 1945-1989 (Krasowski, 1995, p. 46). The first breakthrough took place at the end of the Stalinist era. Following the so called "October thaw" of 1956, many permits to construct new churches and chapels were granted. Between January 1957 and May 1958, voivodeship authorities granted 245 permits for the construction of new religious buildings, i.e. more than twice as many as in the whole post-war period. This was not received well by central authorities. In June 1958, an instruction was issued stating that such permits could be granted only in exceptional cases - after prior approval by the Office for Religious Affairs. As a result, between 1958 and 1960, the Catholic Church was granted permission to construct religious buildings in only $2 \%$ of the cases. Lack of building materials (even if they were already in the possession of the investor) or the fact that enough churches to meet the religious needs of the population already existed, were used most often to justify such refusals. In addition, even if a building permit had been granted, the authorities made every effort to prevent the purchase of land for construction or they revoked the earlier decision.

Such policy led to many social tensions, the so called "Kraśnik events" being a clear example of them. As a result, the Political Bureau of the Central Com- 
mittee of the Polish United Workers' Party and Head of the Office for Religious Affairs - Jerzy Sztachelski, issued special guidelines for the voivodeship administration that aimed at severely restricting religious building construction. Interestingly, the only concessions in this respect were granted to "the priests who were known for their loyalty to the state". The guidelines remained in force until December 1970 (Dudek \& Gryz, 2003, pp. 163-171). On 1 April 1971, the Polish Episcopal Conference issued a letter to Prime Minister Piotr Jaroszewicz concerning the construction of new places of worship. It stated that about 500 churches and 300 chapels were needed in the whole country. In the later period, the policy of the Communist authorities did not change significantly; however, Communist officials, fearing conflicts with the people, avoided demolishing religious buildings which had already been erected without the required permission. At the same time, decisions concerning church building were made at a political rather than an administrative level (Pawlicka, 2004, pp. 71-93).

Following the political overturn of the early 1980s, the policy of the authorities towards religious building construction became less restrictive, just as it was the case after the changes in October 1956. Jan Żaryn notes that in 1981 the Communist authorities and the Polish Episcopate signed an agreement concerning construction of religious buildings, as a result of which more building permits were granted. On the other hand, various media campaigns were launched implying that, for example, the Church "fed on the poorest when building magnificent parish houses" (2003, p. 552). In the aftermath of this agreement, in 1981, the construction of 38 religious buildings began in the Diocese of Przemyśl, for example. Jan Musiał states that most construction work was carried out with the consent of the authorities, but when places of worship were erected with no such consent, this did not entail legal consequences (2003, p. 127).

As historical findings show, the religious policy concerning the construction of religious buildings and legal instruments that were employed to achieve the goals, changed over time. However, there are no analyses regarding detailed trends in this policy, political factors that influenced how it changed, legislation in force relating to the construction of religious buildings, as well as the correlation between political aims in this regard and the application of law.

\section{The phenomenon of Diocese of Przemyśl}

A review of all published studies on religious policy of the Communist authorities shows that the issue of religious building construction has been examined only 
in the Diocese of Przemyśl and only in the period when it was in the pastoral charge of Bishop Ignacy Tokarczuk. His aim was to organize pastoral care in the diocese in such a way that there would be at least one parish church for 10,000 town residents, while village residents would have no more than two to four kilometres to get to the closest church (Tokarczuk, 1989, p. 55). The implementation of this plan required extensive construction work, which met with strong opposition from the Communist authorities.

From the pastoral point of view, new churches in the Diocese of Przemyśl were most needed in urban centres, especially in Rzeszów, Tarnobrzeg, Stalowa Wola, and Krosno (Rudnicka, 1991, p. 85). Yet, it was the most difficult to build churches in cities, because they were designed with a view to creating a new secularized society. Rzeszów can be a good case in point here. Witold Jedynak points out that in the years 1945-1946, as many as 19 new parish churches were built in the city thanks to the determination of its residents and priests. Taking into account the communities incorporated into the city of Rzeszów after its administrative borders had been expanded, 24 new churches were erected there. Because the authorities refused to give their consent for constructing or extending religious buildings, parishioners built them illegally. The following reasons for refusing building permits or not allocating building materials are mentioned by Jedynak: nuisance that new churches would create for the residents of housing estates (ringing bells, music or singing); more urgent needs (hospitals and schools); or the fact that churches were not recognised as public buildings in the Polish law (Jedynak, 2011, pp. 23-27).

Despite the official ban on church building imposed by the Communist authorities, about 400 buildings of worship and nearly as many catechetical and parish houses were built; 173 Greek Catholic churches were reclaimed, restored and renovated for religious purposes, and 225 new parish churches were erected in the Diocese of Przemyśl between 1965 and 1989 (Jedynak, 2007, p. 378). It was not only new churches that were built without the authorities' consent. Also, wayside shrines and cemetery chapels were rebuilt (in Przechody, Czerwona Wola, or Sielec), whereas buildings that had been abandoned or planned for other purposes were adapted for religious use. Sometimes abandoned public buildings, for example an old school (in Lublica), an abandoned warehouse (in Kotowa Wola), or a dance hall (Czudowice) were taken over by the Church. The available studies point out that most churches were constructed illegally in the 1970s (Rudnicka, 1991, p. 86), but the fundamental change in the policy of administrative authorities concerning religious building construction in the Diocese of Przemyśl took place after 1980. In 1981, a total of 90 permits for different construction work were granted in this 
diocese ( 44 for the construction or extension of churches, 20 for the construction of catechetical homes, and 26 for the construction of parish houses). This trend that could be observed also in other regions in Poland continued until the fall of communism (Bełch, 2003, p. 226) and can be explained by social and political transformations in the 1980s. (Kała, 2004, p. 196).

The studies published so far contain brief accounts of how construction work was carried out and of penal and administrative sanctions suffered by those who were involved in illegal church building in some towns of the Diocese of Przemyśl (Bełch, 2003, pp. 219-225). The sanctions included: fines, detention, deprivation of liberty, intimidation, confiscation of property, interrogations, intimidation by security force functionaries, and even a ban on building a shop in a town where church construction was started illegally (Musiał, 2003, pp. 117-128).

An interesting research issue is connected with assessing the legitimacy of actions that the security officers were taking in order to prevent the construction of churches, as well as social resistance to these actions. Some interesting examples of such resistance can be found in the accounts and studies published so far. For example, in Rzeszów, people protested against building a shopping centre under MO (the Citizens' Militia - national police of the Polish People's Republic) and SB (Security Service) guard, on a plot of land designated for the Church of Our Lady of La Salette In Słocin (Wierzbieniec, 2005, p. 69), the MO officers took over a plot of land designated for a church building and used it as a storage place for old cars, removing liturgical objects from a makeshift chapel. Additionally, in unedited archival materials, one can come across the information that plots of land owned by private individuals who were suspected of planning to give them to religious associations for investment purposes, were taken over; there were also attempts to intimidate those people, dismiss them from work or deprive them of tied accommodation. An interesting example of repressions against town inhabitants who were involved in the illegal construction of a church was collecting all tax arrears from them, whereas those who did not participate in the church construction had their tax debts cancelled.

Attention should also be paid to sociological aspects of church building, especially its role in developing a parish community, establishing interpersonal relations, or mobilising opposition to the Communist authorities. Jedynak shows a relationship between church building and the religious and moral growth of the faithful, and the influence that illegal church construction had on integrating the community in the Podkarpacie region. He points out the pastoral context for church building: in the case of rural areas, new churches were built to shorten considerable distances that the faithful had to cover to 
get to the nearest church, whereas in cities - to create a network of parishes that would make it possible for priests to develop close bonds with the faithful (Jedynak, 2010, pp. 9-11). In his studies, Jedynak emphasises enormous public support for Bp. Tokarczuk's decision to disobey the existing law on religious building construction, as well as the assistance provided by the Church institutions to the faithful who suffered sanctions because of their involvement in church building. He also stresses that attempts to block construction work made by the Communist authorities (for example, through police supervision) met with collective resistance, and that churches were built under the pretext of constructing some other buildings. He describes the process of building a church: first a collective decision to erect a church was taken by local residents, then they elected a church building committee, and finally carried out construction work using their own resources. This prevented the Communist authorities from effectively hampering the construction process, and at the same time contributed to the growth of religiosity (Jedynak, 2008, pp. 211-213). According to Jan Draus, one effect of illegal construction of religious buildings in the Przemyśl Diocese was that the people's resistance "shifted over time to other levels of social and then political life" (Draus, 2003, p. 111).

Another issue that is undoubtedly worth further in-depth research is connected with how the Communist authorities used conflicts over the ownership of churches between Roman Catholics, Greek Catholics, Orthodox Christians and members of the Reformed Churches. These conflicts arose mainly in the areas affected by resettlement, where abandoned places of worship that had belonged to one denomination were handed over to some other one or seized by the State Treasury. Very little information on this subject has been published so far. Żaryn notes that 166 out of 540 Greek Catholic churches that had been abandoned after World War II were used by Roman Catholics. Some information on this subject can be found in the works dealing with Polish-Ukrainian relations after World War II, and especially with the so called "Operation Vistula" (Wojewoda, 1994, pp. 51-73). It is worth remembering that the aim of "Operation Vistula" was to relocate Ukrainians (primarily Ukrainian Greek Catholics) in such a way as to prevent them from creating compact groups, which in turn forced them to attend religious services in the Roman Catholic churches. Certainly, the way the Communist authorities treated the Greek Catholic Church, which was considered to be legally non-existent after Bishop Jozafat Kocyłowski and his Sufragan, as well as the Chapter and members of the Episcopal Curia had been all expelled in June 1946, was in line with the nationalist policy of the Polish People's Republic (Biłas, 1996, pp. 277-289). So far, the only publication devoted in its entirety to 
the legal status of the Greek Catholic Church in the Polish People's Republic is a short article by Paweł Pelc, where he also mentions ownership issues related to the estate abandoned by the Greek Catholic Church following resettlements (Pelc, 1992, pp. 107-121). Only one article that deals with the legal status of the Uniate churches has been published to date (Musiał, 1990, pp. 257-262). As it has already been established, this issue has been studied only in the territory of the Roman Catholic Diocese of Przemyśl at that time. In 1961, the Department for Religious Affairs in Rzeszów ordered to close empty Greek Catholic churches and to convert them into fertilizer warehouses and utility buildings (Bober, 2000, p. 119; see Balicki, 2014, pp. 20-56). Bishop Tokarczuk, who helped to save historic church buildings or allowed the Uniate priests to study in the Przemyśl Seminary, was proclaimed by the Security Service to be a supporter of the Ukrainian nationalists (Pawlicka, 2004, p. 84). In one of his articles, Stanisław Nabywaniec discusses a few examples of conflicts over the ownership of churches that were instigated by the administration for religious affairs in the Rzeszów voivodeship. He also lists 57 Greek Catholic churches that Bp. Tokarczuk managed to reclaim for worship (Nabywaniec, 2003, pp. 129-139).

\section{Conclusion}

Polish People's Republic treated the law regulating the construction of religious buildings merely as an instrument for achieving their political goals. The administrative decisions and other actions that were taken at that time often lacked the legal basis and were an example of an instrumental application of law, being based on non-legal criteria discriminating some religious associations.

In the years 1945-1989, it was not so much religiosity that was fought against, but rather the influence of the Roman Catholic Church, which was believed to be the main enemy of the Polish People's Republic. On the other hand, development of other religious associations and their facilities was generally supported. As a result, exercising the right to freedom of conscience and religion guaranteed in the Constitution, depended on whether a person belonged to a religious community that was either favoured or disliked by the Communist authorities.

Restrictions and limitations imposed by the Communist authorities on church building were meant to be a way of preventing the development of religious communities. However, as research shows, legal provisions regulating the construction of religious buildings were not applied uniformly in relation to different religious associations in the territory of the Polish People's Republic. It 
has been assumed that the main factor differences in the treatment of religious associations by the Communist authorities was how the political attitude of their leaders, priests and lay members was viewed and assessed. A detailed analysis of the Communist policy in regard to religious building construction will allow to explain unresolved issues concerning the law on religion in force at that time. These include: differentiating the legal position of religious associations on the basis of political and religious criteria, using property ownership conflicts between different communities and treating them in an instrumental way to achieve the political goals that the Communist authorities set themselves.

\section{Bibliography}

\section{Normative acts}

Konstytucja Polskiej Rzeczypospolitej Ludowej uchwalona przez Sejm Ustawodawczy w dniu 22 lipca 1952 r., Dz.U. 1952, nr 33, poz. 232 with subsequent amendments. Ustawa z dnia 31 stycznia 1961 r. - Prawo budowlane, Dz.U. 1961, nr 7, poz. 46 with subsequent amendments.

Ustawa z dnia 24 października 1974 r. - Prawo budowlane, Dz.U. 1974, nr 38, poz. 229 with subsequent amendments.

Ustawa z dnia 17 maja 1989 r. o stosunku Państwa do Kościoła Katolickiego w Polskiej Rzeczypospolitej Ludowej, Dz.U. 1989, nr 29, poz. 154 with subsequent amendments.

Ustawa z dnia 17 maja 1989 r. o gwarancjach wolności sumienia i wyznania, Dz.U. 1989, nr 29, poz. 155 with subsequent amendments.

Zarządzenie nr 47 Prezesa Rady Ministrów z dnia 24 listopada 1981 r. w sprawie planowania i realizacji inwestycji sakralnych i kościelnych (unpublished). Archives of Modern Records in Warsaw, group 1587, files no. 136/36, pp. 73-76.

Okólnik nr 3 Kierownika Urzędu do Spraw Wyznań z dnia 27 marca 1957 r. w sprawie budownictwa obiektów sakralnych i kościelnych oraz zaopatrywania tych obiektów w materiały budowlane. (1957). Wiadomości Diecezjalne Lubelskie, 31 (4), 115-116.

\section{Literature}

Balicki, M. (2014). Stan prawny nieruchomości Archieparchii Przemysko-Warszawskiej w latach 1944-2014. Lublin: Wydawnictwo KUL.

Bełch, K. (2003). Strategie duszpasterskie arcybiskupa Ignacego Tokarczuka. W: J. Zimny (red.), Arcybiskup Ignacy Tokarczuk w oczach społeczeństwa (pp. 217-228). Sandomierz: Wydawnictwo Diecezjalne.

Biłas, I. (1996). Likwidacja greckokatolickiej diecezji przemyskiej oraz tragiczne losy jej ordynariusza bp. Jozafata Kocyłowskiego w kontekście polityki wyznaniowej 
ZSRR. W: S. Stępień (red.), Polska-Ukraina 1000 lat sąsiedztwa. Studia z dziejów greckokatolickiej diecezji przemyskiej (pp. 70-95). Przemyśl: Południowo-Wschodni Instytut Naukowy.

Bober, S. (2000). Spór o cerkwie greckokatolickie w diecezji przemyskiej za rządów biskupa Ignacego Tokarczuka. Biuletyn Ukrainoznawczy, 1(6), 118-124.

Borcz, H. (2009). Nieudana próba likwidacji przez władze komunistyczne parafii rzymskokatolickiej w Wołkowyi w Bieszczadach (na kanwie dramatycznych wydarzeń 3-4 października 1967 r.). W: J. Izdebski, K. Kaczmarski, \& M. Krzysztofiński (red.), Bieszczady w Polsce Ludowej (pp. 279-319). Rzeszów: Instytut Pamięci Narodowej. Draus, J. (2003). Arcybiskup Ignacy Tokarczuk a opór społeczny w diecezji przemyskiej. Studia Rzeszowskie, 1(10), 109-116.

Dudek, A. (1995). Państwo i Kościót w Polsce 1945-1970. Kraków: PiT.

Dudek, A., \& Gryz, R. (2003). Komuniści i Kościół w Polsce (1945-1989). Kraków: Znak. Godlewski, J. F., \& Jabłoński, K. H. (1988). Prawo a religia. Warszawa: Wiedza Powszechna. Jedynak, W. (2007). Wpływ nielegalnego budownictwa sakralnego na uaktywnienie apostolatu ludzi świeckich w państwie totalitarnym na przykładzie diecezji przemyskiej. Studia Sandomierskie, 14(2-4), 377-387.

Jedynak, W. (2008-2009). Integracja społeczności kościelnych w katolickiej myśli społecznej i w działalności przemyskich biskupów-społeczników (w XX wieku). Premislia Christiana, 13, 187-215.

Jedynak, W. (2010). Wpływ budownictwa sakralnego na zmiany zachowań religijno-moralnych katolików w diecezji przemyskiej. Społeczeństwo i Rodzina, 3(23), 8-22.

Jedynak, W. (2011). Rozwój struktur parafialnych w Rzeszowie: analiza socjologiczno-pastoralna, Społeczeństwo i Rodzina. Społeczeństwo i Rodzina, 4(29), 22-37.

Kała, M. (2004). Formy administracyjnego zwalczania Kościoła katolickiego na Dolnym Śląsku po II wojnie światowej. W: A. Bogaczewicz, \& S. Krzyżanowska (red.), Represje wobec Kościoła katolickiego na Dolnym Ślasku i Opolszczyźnie 1945-1989 (pp. 179-206). Wrocław: Instytut Pamięci Narodowej.

Krasowski, K. (1995). Państwo a Kościół katolicki w Polsce Ludowej. Czasopismo Prawno-Historyczne, 47(1-2), 45-59.

Misztal, H. (1997). Polskie prawo wyznaniowe. Zagadnienia wstępne. Rys historyczny. Lublin: Wydawnictwo KUL.

Musiał, J. (1990). Stan prawny i sytuacja faktyczna świątyń unickich na terenie diecezji przemyskiej w latach 1945-1985. W: S. Stępień (red.), Polska-Ukraina 1000 lat sasiedztwa: t.1. Studia z dziejów chrześcijaństwa na pograniczu etnicznym (pp. 257-262). Przemyśl: Południowo-Wschodni Instytut Naukowy.

Musiał, J. (2003). Represje wobec budowniczych kościołów w diecezji przemyskiej. Studia Rzeszowskie, 10(1), 117-128. 
Nabywaniec, S. (2003). Działania Biskupa Ignacego Tokarczuka na rzecz ratowania cerkwi greckokatolickich. Studia Rzeszowskie, 10(1), 129-139.

Pawlicka, K. (2004). Polityka władz wobec Kościoła katolickiego (grudzień 1970-października 1978). Warszawa: Trio.

Pelc, P. (1992). Położenie prawne Kościoła greckokatolickiego w Polsce w latach 19451989. Więź, 35(7), 107-121.

Rudnicka, M. (1991). Budownictwo sakralne misją trudnych czasów. W: J. F. Adamski, \& M. Rudnicka (red.), Księga jubileuszowa 25 lat pasterskiego postugiwania ks. biskupa Ignacego Tokarczuka (pp. 88-97). Brzozów: Muzeum Regionalne PTTK.

Tokarczuk, A. (1989). Budowa kościoła parafialnego w służbie tworzenia wspólnoty kościelnej. Ateneum Kapłańskie, 113(1), 50-61.

Wierzbieniec, W. (2005). Instytucjonalizacja życia religijnego w Rzeszowie po II wojnie światowej. W: K. Kaszuba, \& Z. Sokół (red.), Rzeszów dawny i wspótczesny. Społeczeństwo (pp. 59-96). Rzeszów: Wyższa Szkoła Zarządzania.

Wojewoda, Z. (2004). Zarys historii Kościoła greckokatolickiego w Polsce w latach 19441989. Kraków: Nomos.

Zieliński, T. J. (2010). Stosunek państwa do mniejszościowych związków religijnych w Polsce Ludowej w perspektywie ówczesnej doktryny prawa konstytucyjnego i wyznaniowego. W: T. J. Zieliński (red.), Władze Polski Ludowej a mniejszościowe zwiazki wyznaniowe (pp. 183-210). Warszawa: Wyższe Baptystyczne Seminarium Teologiczne.

Żaryn, J. (2003). Dzieje Kościoła katolickiego w Polsce (1944-1989). Warszawa: Neriton.

\section{Summary}

The article deals with the most important issues of law and religious policy of the People's Republic of Poland in the field of religious building construction. Licensing of permits for the implementation of construction projects by religious associations, especially the Catholic Church and the repression of people and communities undertaking illegal construction of religious and ecclesiastical buildings was one of the main forms of conducting religious policy by the authorities of the People's Republic of Poland. At the same time, uniform provisions of the law in force in this matter were applied in an extremely diverse way (both within individual units of the Catholic Church and non-Roman Catholic religious associations), depending on extra-legal political and religious factors. Therefore, the issue of sacred buildings is one of the clearest examples of instrumentalisation of the law - both at the level of its establishment and application - in the activities of the authorities of the People's Republic of Poland.

KeYwords: religious building construction, Polish People's Republic, law on religion, religion policy. 


\section{Streszczenie}

Artykuł traktuje o najważniejszych zagadnieniach prawa i polityki wyznaniowej PRL w zakresie budownictwa sakralnego. Koncesjonowanie zezwoleń na realizację inwestycji budowalnych przez związki wyznaniowe, zwłaszcza Kościół Katolicki, oraz represjonowanie osób i wspólnot podejmujących nielegalne budowy obiektów sakralnych i kościelnych było jedną z głównych form prowadzenia polityki wyznaniowej przez władze Polski Ludowej. Jednocześnie jednolite przepisy obowiązującego w tej materii prawa aplikowano w niezwykle zróżnicowany sposób (zarówno w ramach poszczególnych jednostek Kościoła Katolickiego, jak i nierzymskokatolickich związków wyznaniowych) w zależności od pozaprawnych czynników natury polityczno-wyznaniowej. Stąd też kwestia budownictwa sakralnego jest jednym z najczytelniejszych przykładów instrumentalizacji prawa - zarówno na poziomie jego stanowienia, jak i stosowania w działalności władz PRL.

SŁowa KLUCzowe: budownictwo sakralne, Polska Rzeczpospolita Ludowa, prawo i polityka wyznaniowa.

\section{Nota o autorze}

Konrad Dyda - mgr; doktorant w Katedrze Prawa Wyznaniowego na Wydziale Prawa, Prawa Kanonicznego i Administracji Katolickiego Uniwersytetu Lubelskiego Jana Pawła II; główne obszary działalności naukowej: prawo i polityka wyznaniowa okresu PRL, system prawa Państwa Watykańskiego; konrad.dyda@gmail.com; ORCID: 0000-0002-2061-7839. 
